\title{
Epidemiology of renal cancer in developing countries: Review of the literature
}

\author{
Mauricio Medina-Rico, MsC(c) ${ }^{1}$; Hugo López Ramos, $\mathrm{MsC}^{2}$; Manuel Lobo; Jorge Romo³ \\ Juan Guillermo Prada ${ }^{3}$ \\ ${ }^{1}$ Department of Clinical Epidemiology and Biostatistics, Faculty of Medicine, Pontificia Universidad \\ Javeriana; ${ }^{2}$ Department of Urology, Faculty of Medicine, Pontificia Universidad Javeriana; ${ }^{3}$ Faculty of \\ Medicine, Pontificia Universidad Javeriana; Bogotá, Colombia
}

Acknowledgement: Financial support for this study was provided by the Pontificia Universidad Javeriana Bogotá, Colombia. The funding agreement ensured the authors' independence in designing the study, interpreting the data, writing, and publishing the report

Cite as: Can Urol Assoc J 2017 Dec. 22; Epub ahead of print. http://dx.doi.org/10.5489/cuaj.4464

Published online December 22, 2017

***

\section{Abstract}

Introduction: Renal cell carcinoma (RCC) is the ninth most common cancer in men, and the 14th most common cancer in women. It has been reported that the incidence of RCC is rising. These changes are more common in developed countries because of better screening programs and disease registry. The aim of this article is to review the epidemiology of RCC around the world.

Methods: A literature review on four databases was performed: PubMed, Embase, Lilacs, and Scielo. Studies of incidence, prevalence, mortality, and survival of RCC were taken from different countries. Studies included were published in the last 10 years. Two reviewers independently selected the studies.

Results: A total of 5275 references were reviewed by title and abstract. In the end, 42 references were selected for full-text review. The global incidence and prevalence of cancer vary. The highest incidence was described in North America and Northern Europe. In Canada, by 2007 the incidence was 17.9/100 000 and 10.3/100 000 in males and females, respectively. Developing countries like Colombia have fewer incidence rates, finding less information in poor-income areas.

Conclusions: We have seen a rise in the incidence and mortality of RCC globally. There is an association between RCC and smoking, obesity, hypertension, and socioeconomic status. Seeing the epidemiological data from some regions in developing countries and the lack of specialists in those places, it can be deduced the existence of an underreporting of 
the disease that reveals the need to improve both surveillance and disease registration programs, especially in these countries.

\section{Introduction}

Renal cell carcinoma (RCC) is the 9th most common cancer in men and 14th in women. In 2012, 143000 deaths by RCC were estimated making it the 16th most common cause of cancer death globally. ${ }^{1}$ In recent decades there has been an increased incidence which has been associated with a better diagnosis of the disease, and a major exposure to different risk factors. ${ }^{2}$ The highest incidence rates could be found in developed countries mainly North and East Europe, and North America. ${ }^{3}$

Unlike other cancers, the incidence and mortality of RCC has had a significant rise globally, being more stable in developed countries like the United States. This associated with better screening programs and disease registration which also has reduced mortality in other countries like France, Germany and Italy. ${ }^{4}$

Some risk factors for the RCC that have been reported are: sex and age, being more prevalent in men and older adults. ${ }^{4}$ However, because of the increased incidence, some studies have identified other associated factors such as: hypertension by chronic use of diuretics, diabetes, urinary tract infections; exposure factors such as smoking, asbestos, radiation and lifestyle factors such as diet and obesity. ${ }^{5}$

In Canada, according to statistics from GLOBOCAN 2012 the number of cases estimated to 2020 for RCC was 4139 in men and 2565 in women with more than 1000 new cases since 2012. Moreover it is reported 1373 deaths in men and 792 in women for 2020, with 400 more deaths since 2012. ${ }^{6}$

While Canada counts with the Canadian Cancer registry, other countries get their epidemiological data from local population bases of cancer. Colombia for example has the oldest database in Latin America with the population registry of cancer in Cali (RPCC), which contains information since $1962{ }^{7}$ However, because of the geographic and sociocultural difference in this country, RPCC information is insufficient to calculate the national epidemiological behavior ${ }^{8}$, situation that also can be seen in other countries.

Given the lack of accurate and recent epidemiological data about RCC, it is necessary to perform a literature search to determine the incidence, prevalence and mortality of this disease around the globe, and see if there is a lack of information in their registries and if possible, identify the aspects in which they fail.

\section{Methods}

A review of the literature was performed in 4 different databases (PubMed, Embase, Lilacs and Scielo), on any information concerning the field of epidemiology in Renal Cancer.

The search criteria were established in the form of free text and indexed terms. To characterize the renal cell carcinoma we use the free terms: "Kidney cancer", "Renal Cancer", "kidney Neoplas *", "Renal Neoplas*". For epidemiological studies the terms 
included in free text were: "incidence" "prevalence", "epidemiology", "mortality", "burden of disease", "cost of illness" and indexed terms: "Incidence" and "prevalence". As restriction, the search was limited to publications in the last 10 years. A gray literature search was also made on the pages of: The National Technical Information Service (NTIS), and the European Association for Grey Literature Exploitation (EAGLE), in which could not be found any relevant information.

The articles should be original studies, which provide epidemiological information on incidence, prevalence, mortality, survival and disease burden for RCC. Studies that describe their information in specific subgroups (Specific histological type, or specific ethnic group) were excluded. References were reviewed by title and abstract, by two reviewers independently. From the first selection of articles references were reviewed in full text ensuring that they give some information of interest mentioned previously about RCC. Duplicate studies were removed, and studies written in any language different from English or Spanish were ignored. Subsequently, the information obtained was analyzed.

\section{Results}

The search yielded a total of 5275 references that were reviewed by title and abstract. In seeking local references 4 studies from non-indexed journals were included. 338 references were selected for full text review, of which 300 were excluded because they did not express epidemiological data of interest (reported data for specific age group or specific ethnicity). References of which full text were not available (poster format or abstract) were excluded as well as those who were in other language different of English or Spanish. 42 articles were finally analyzed for data extraction, of which 8 belong to Latin American literature (Figure 1).

All studies were observational; most of them were cross-sectional studies that drew their information from databases of each country. A limitation of the review lies in the methodology of most of the studies, since disease registration programs have a different

quality and coverage in each country, preventing a proper comparison of the results. ${ }^{9}$ Yang et al for example refers to a possible underreporting of disease. ${ }^{10}$ Also, Villanueva et al in his study discusses the need to improve epidemiological surveillance programs, and the creation of better prevention and treatment programs. ${ }^{11}$

Among the included studies, 14 assessed populations from Europe, 14 from America of which 8 correspond to Latin American literature, 2 global studies, 8 from Asia and Oceania, and 4 from Africa and the Middle East.

\section{Global data}

Patel et al. found the highest incidence in North America of 11,8/100 000 population. $^{3}$ Znaor et al. describes the incidence and mortality rates between 2003 and 2007, the highest was found in Europe, specifically in Czech Republic; the lowest were located in Asia, mainly Thailand and Korea. ${ }^{1}$ Patel et al. refers to the characteristics of each population 
(genetics and exposure to risk factors), as well as socioeconomic level as possible explanation for the epidemiological differences between countries, finding higher incidences in developed countries and an increased mortality in development countries. ${ }^{3}$ Znaor et al. also concludes an overall increase in the incidence of RCC due to the development of better diagnostic techniques. ${ }^{1}$ (See Table 1.)

\section{Europe studies}

Four studies evaluated multiple countries. The study by Ljungberg et al. found a gender difference being 15,8/100 000 in men and 7,1/100 000 in women; it also concludes that both incidence and mortality have been declining due to the reduced cigarette consumption in these population and better occupational hygiene. ${ }^{4}$ The remaining studies were conducted in Germany, Holland, Italy, England, Scotland, Ireland, Denmark and Spain for a total of 10 studies. The highest incidence was found in Germany and Holland being in the last one 16,9/100 000 in men, and 9,2/100 000 in women. ${ }^{12,13}$ The lowest was found in Spain with 8,2/100 000 in men and 3,7/100 000 in women between 2003-2007; ${ }^{14}$ with a tendency to increase. ${ }^{15}$ Ireland also has an increase tendency, Falebita et al. associates this findings with better diagnosis and registration. ${ }^{16}$ Wihlborg et al. study made in Denmark describes a change over time, rising from 3,95/100.000 between 1944-1948 to 7,30/100 000 between 1969-1973, and decreases to 7,01/100 000 between 1999-2003; taking as an explanation the improvements in diagnosis for the ascent time lapse and the decrease in cigarette consumption for the descent one. ${ }^{17}$ Also the study by Maruthappu et al. in England found differences by ethnicity, being the largest one in white population, regarding: Pakistani, Asian, African and Indian. ${ }^{18}$

Mortality was assessed in 8 articles, three with information from multiple countries. The highest mortality was found in Czech Republic of 9/100 000 in men and 3,7/100 000 in women, the lowest was found in Greece, Portugal, and Luxembourg. ${ }^{19}$ Most studies agree that mortality is decreasing, associated with more timely diagnosis, better treatments and less tabaco consumption. ${ }^{2,419}$ The other 5 studies were conducted in Holland, Ireland, Italy and 2 in Spain. The highest mortality was found in Holland of 7,3/100 000 in men and 3,8/100.000 in women. ${ }^{13}$ The lowest was found in Italy of 2,39/100 000 in men and $1,61 / 100.000$ in women. ${ }^{20}$ Although some studies describe a decrease in mortality, other studies like Opeyemi et al. in Ireland shows an increase in mortality in recent decades from 3,6/100.000 in 1994 to 4,7/100.000 2004 for both sexes. ${ }^{16}$

The 5-year survival was evaluated in four articles; one was conducted in multiple countries. The study made by Mark-Gragera et al. found differences by region being the largest in Central Europe of 64,6 \% and lowest in Northern Europe of 55,8 \%; this contrast because of the difference in diagnosis and intervention programs in each country. ${ }^{9}$ The other 4 studies were conducted in Ireland, Denmark and Scotland, the last one having the lowest survival between $39 \%$ and $42 \% .{ }^{21}$ Among the related factors a better diagnosis and intervention, as well as socioeconomic and educational level were found. ${ }^{22}$ 


\section{Asia and Oceania}

Eight studies were found from: Japan, China, Korea and Australia. Japan had the highest incidence rates for RCC, Marugame et al. showed an incidence of 11,6/100 000 in men and 5,6/100 000 in women. ${ }^{23}$ Also Marumo et al. shows an increased incidence in this country and the need to study its relationship with known risk factors. ${ }^{24}$ Similarly, Yang et al. mentions an increase in the incidence of renal cancer. ${ }^{10}$ Zheng et al. discusses how the prevalence of cancer is higher in urban areas compared to rural ones and how this is associated with increased life expectancy. ${ }^{25}$ In Korea the incidence was slightly lower than in Japan, furthermore Jung et al. describes mortality in men of 2,3/100 000 and 0,9/100 000 in women, with a 5-year survival of 77,7 \%. ${ }^{26,27}$ Articles of Australia respectively show an increase in both the incidence and survival in the last 5 years. ${ }^{28,29}$

\section{Africa and Middle East}

Four studies were found from: Saudi Arabia, Pakistan, Morocco and Iran. The lowest incidence was found in Pakistan of 1,4/100 000 in 2012. ${ }^{30}$ The other studies make mention of the impact on their countries, three of which agree that the rate has been increased in recent years; ${ }^{31-33}$ The study of Mirzaei et al. associates it with a better record of the disease and an increased exposure to risk factors. ${ }^{32}$

\section{America}

In America 14 articles were found, six from North America and 8 from Latin America. The study of Pinheiro et al. conducted in the US found similar incidence rates among different ethnic groups, being slightly higher in white people (18/100 000 in men, 8,7/100 000 in women), followed by hispanics (17,3/100 000 in men, 7,7/100 000 in women) and finally black people (14,7/100 000 in men, 7,2/100 000 in women). ${ }^{34}$ Some studies showed an increase incidence rate over the years; Gandaglia et al. for example, describes an incidence of 2,99/100 000 in 1975 compared to 12,16/100 000 in 2009. This increase was associated with improvements in diagnostic techniques and aging population. However, they suggest the needs to investigate a possible increase in risk factors. ${ }^{35}$ Otterstatter et al. in Canada showed similar results, finding an increased incidence rate and risk factors like obesity and hypertension. ${ }^{36}$ In terms of mortality, the study of Gandaglia et al. made in the US, found an increase tendency in recent years of 2,24/100 000 in 1975 to 5/100 000 in 2009. ${ }^{35}$ On the other hand, a study made in Canada estimates to 2025 a mortality for kidney cancer of $17,9 / 100000$ in men and 8,7/100 000 in women. ${ }^{36}$

As the burden of disease, a study made in the United States found a cost of disease of 4,4 billion dollars for 2005, which meant an average 40.176 dollars per patient. ${ }^{37}$ Also, Chunyo et al. showed the potential years of life loss (PYLL) for Caucasian American population being 129216 to 2004. ${ }^{38}$ Mohamed et al. found that the PYLL has been increasing in recent decades, which has made RCC a disease that should be worrisome for 
urologists and the health system. ${ }^{39}$ Finally it was found that 5-year survival of patients in the US to 2005 was 64,9\%, similar in Canada of $68 \%$. ${ }^{35,36}$

Eight studies were found in Latin American literature the one written by Chatenoud. $L$ et al evaluated multiple countries in which it is possible to observe the highest mortality found in Uruguay in men and women of 5,97/100 000 and 2,32/100 000 respectively; and the lowest one in Ecuador of 1,17/100000 in men and 0,76/100 000 in women. ${ }^{40}$ The other studies were made mainly from: Colombia, Mexico and Chile. The highest incidence rate was found in Chile being 6,95/100.000 in general population. ${ }^{41}$ Villanueva et al. study found an overall incidence for Mexico of 2,5/100 000. ${ }^{11}$ Mortality showed a stability with 2,3/100 000 in men and 1,34/100.000 in women to 1999 and 2,35/100 000 in men and 1,34/100. 000 in women to $2007 .^{42}$

In Colombia, Pardo C et al. found an incidence of 2,7/100 000 in men and 1,9/100 000 in women. The highest rates were found in Risaralda and Quindío and the lowest in Chocó and Amazonas. Mortality was found to be 1,1/100 000 in men and 0,7/100 000 in women and a survival at 5 years of 51,9\%. ${ }^{43}$ For 2003 and 2007 Manizales was the city with the highest incidence (3,4/100 000 in men and 2,4/100 000 in women), followed by Bucaramanga (2,4/100 000 in men, 1,3/100 000 in women), and finally the city of Pasto $\left(1,7 / 100000\right.$ in men and 1,4/100 000 in women). ${ }^{44-46}$

\section{Discussion}

A global difference in RCC incidence, mortality, and survival rates could be observed. The highest incidence was found in Europe, mainly in the Czech Republic and Denmark; followed by North America, Australia, South America and Asia. At the same time, higher mortality was found in Europe, and the lowest one in Asia. The study carried out by Patel A et al. and Znaor et al, are two examples in which we can see the epidemiological difference of each country. However they are also an example of the limited information about epidemiology rates that could be found in development countries like Colombia., ${ }^{1,2}$

In every country the incidence rates seems to have a tendency to rise. However, studies like the ones made by Ljungberg et al and Clèries et al mentioned a stabilization of incidence rate in recent years. This result, being the product of good disease registration programs as well as better control of risk factors. ${ }^{4,14}$ The study that measure mortality made by Levi et al and Bosetti et al, show a decrease of this rate over the years. ${ }^{2,19}$ Despite the findings we can't ensure that these trends are shared in other regions given the different opportunities of each country have because of their diagnostic technologies and reliability in disease registration programs. The study carried out by Yang et al or Wojcieszak et al mention the existence of an underreporting. ${ }^{10,47}$, this can make it difficult to compare the data between countries.

The comparison problem can be observed in the data from the IC5 (Incidence of cancer in 5 continents), in which can be seen the number of cases in each country, but more important can be assessed the quality of the records by values such as: the MV\% 
corresponding to those cancers recorded with microscopic verification, the DCO\% that are obtained from death certificates and the MI\% that is the ratio between mortality and incidence of a cancer in a given period. Having an estimate for each value in kidney cancer it can be perceived a higher number of cases reported by death certificates in Latin America. On the other hand there is an underreporting in death certificates reports in Africa, observing a higher quality in the registries of European countries and North America ${ }^{48}$.

It is of interest to us studies such as Patel A et al or Eriksen $T$ et al, who found a relationship between incidence and socioeconomic status, seeing a lower incidence in countries with fewer resources. ${ }^{3,22}$ This can be seen in Latin America and Africa. These findings may be seen in other aspects such as survival at 5 years, Danzig $M$ et al for example describes a lower survival in these countries ${ }^{49}$.

Although several studies identified as potential elements associated with epidemiological differences greater exposure to risk factors such as smoke, diet, obesity and hypertension, it requires deeper research about these factors and their role in the development of RCC. Another interesting fact is the difference by sex and race taking in all studies comparing these populations, finding a higher incidence and mortality rate in men compared to women, and white populations compared to Hispanic, black and Asian people. Finally, given the increasing incidence rate of RCC it is clear the necessity to study a way to facilitate the implementation of prevention, risk factors control, screening programs, and early intervention to enable timely intervention of the RCC.

Knowing that most small renal masses are discovered incidentally it is important that sub-registration can also be found in mortality rates given that there are deaths that may end up associated with causes other than cancer itself ${ }^{48}$.

The overall incidence of RCC in developed countries like Canada appears to be higher than other countries with an increase in the last two decades. On the other hand development countries like Colombia appears to be lower compared to Europe and North America. However being an example of a country with registration difficulties because of the epidemiological differences throughout the country, being the areas with lower rates, the departments characterized for their poor incomes such as Chocó and Colombian Amazonas. This finding may be associated with greater difficulties in access to health care services, and medical specialists making Urology a specialty virtually nonexistent in such places ${ }^{50}$, which contributes with lesser diagnosis and disease registry.

\section{Conclusion}

Our study identifies some of the risk factors that deserve attention for future research such as: obesity, smoke and hypertension. It was found as a point of interest the association between socioeconomic status differences and the epidemiological rates in the different countries, and programs detection and registration of disease programs. This review allowed an approach to the epidemiology of RCC in America and the rest of the world. 
Finally, it was shown that the incidence of RCC has been increasing in recent years globally, showing the need to create and / or improve the public health policies aimed at improving the diagnosis and treatment of patients with RCC. 


\section{References}

1. Znaor A, Lortet-Tieulent J, Laversanne M, Jemal A, Bray F. International variations and trends in renal cell carcinoma incidence and mortality. Eur Urol. 2015 Mar;67(3):519-30.

2. Levi F, Ferlay J, Galeone C, Lucchini F, Negri E, Boyle P, et al. The changing pattern of kidney cancer incidence and mortality in Europe. BJU Int. 2008 Apr;101(8):949-58.

3. Patel AR, Prasad SM, Shih Y-CT, Eggener SE. The association of the human development index with global kidney cancer incidence and mortality. J Urol. 2012 Jun;187(6):1978-83.

4. Ljungberg B, Campbell SC, Choi HY, Cho HY, Jacqmin D, Lee JE, et al. The epidemiology of renal cell carcinoma. Eur Urol. 2011 Oct;60(4):615-21.

5. $\quad$ Pascual D, Borque A. Epidemiology of kidney cancer. Adv Urol. 2008;782381.

6. GLOBOCAN 2012. Cancer Incidence, Mortality and Prevalence Worldwide Canada, Kidney [Internet]. 2017 [cited 2017 Jul 19]. p. 1. Available from: http://globocan.iarc.fr/old/burden.asp?selection_pop=31124\&Text$\mathrm{p}=$ Canada\&selection_cancer $=10210 \&$ Text$\mathrm{c}=$ Kidney\&pYear $=8 \&$ type $=0 \&$ window $=1$ \&submit $=$ Execute

7. Bravo LE, Collazos T, Collazos P, Garcia L, Correa P. Trends of cancer incidence and mortality in Cali, Colombia. 50 years experience. Colomb medica (Cali, Colomb. 2012;43(4):246-55.

8. Pineros M, Ferlay J, Murillo R. Cancer incidence estimates at the national and district levels in Colombia. Salud Publica Mex. 2006;48(6):455-65.

9. Marcos-Gragera R, Mallone S, Kiemeney LA, Vilardell L, Malats N, Allory Y, et al. Urinary tract cancer survival in Europe 1999-2007: Results of the population-based study EUROCARE-5. Eur J Cancer. 2015 Sep 5;

10. Yang Y, Xie L, Zheng J-L, Tan Y-T, Zhang W, Xiang Y-B. Incidence trends of urinary bladder and kidney cancers in urban Shanghai, 1973-2005. PLoS One. 2013;8(12):e82430.

11. Gomez-Villanueva A, Chacon Sanchez J, Santillan Arreygue L, Sanchez Gonz??lez $\mathrm{Y}$, Romero-Figueroa M del S. Incidencia de cancer en una unidad de atencion oncologica del instituto mexicano del seguro social (IMSS), en Toluca, Estado de Mexico. Gac Med Mex. 2014;150(4):297-303.

12. Stang A, Büchel C. A novel approach for estimating the nationwide incidence of renal cancer. Emerg Themes Epidemiol. 2014;11:8.

13. van de Schans SAM, Aben KKH, Mulders PFA, Haanen JBAG, van Herpen C, Verhoeven RHA, et al. Modest improvement in 20 years of kidney cancer care in the Netherlands. Eur J Cancer. 2012 Aug;48(12):1822-30. 
14. Clèries R, Esteban L, Borràs J, Marcos-Gragera R, Freitas A, Carulla M, et al. Time trends of cancer incidence and mortality in Catalonia during 1993-2007. Clin Transl Oncol. 2014;16(1):18-28.

15. Souza DLB, Bernal MM. [Incidence, prevalence and mortality of kidney cancer in Spain: estimates and projections for the 1998-2022 period]. Actas Urol españolas. 2012 Oct;36(9):521-6.

16. Falebita OA, Mancini S, Kiely E, Comber H. Rising incidence of renal cell carcinoma in Ireland. Int Urol Nephrol. 2009;41(1):7-12.

17. Wihlborg A, Johansen C. Incidences of Kidney, Pelvis, Ureter, and Bladder Cancer in a Nationwide, Population-based Cancer Registry, Denmark, 1944-2003. Urology. 2010;75(5):1222-7.

18. Maruthappu M, Barnes I, Sayeed S, Ali R. Incidence of prostate and urological cancers in England by ethnic group, 2001-2007: a descriptive study. BMC Cancer. 2015;15:753.

19. Bosetti C, Bertuccio P, Chatenoud L, Negri E, La Vecchia C, Levi F. Trends in mortality from urologic cancers in Europe, 1970-2008. Eur Urol. 2011 Jul;60(1):115.

20. Arfè A, Malvezzi M, Bertuccio P, Decarli A, La Vecchia C, Negri E. Cancer mortality trend analysis in Italy, 1970-2007. Eur J Cancer Prev. 2011 Sep;20(5):36474.

21. Westlake S, Cooper N, Rachet B, Coleman MP. Survival from cancers of the kidney and ureter in England and Wales up to 2001. Br J Cancer. 2008 Sep 23;99 Suppl 1:S93-5.

22. Eriksen KT, Petersen A, Poulsen AH, Deltour I, Raaschou-Nielsen O. Social inequality and incidence of and survival from cancers of the kidney and urinary bladder in a population-based study in Denmark, 1994-2003. Eur J Cancer. 2008 Sep;44(14):2030-42.

23. Marugame T, Matsuda T. Comparison of time trends in kidney cancer incidence (1973-97) in East Asia, Europe and USA, from cancer incidence in five continents, Vols IV-VIII. Jpn J Clin Oncol. 2008 Jul;38(7):508-9.

24. Marumo K, Kanayama H, Miyao N, Nakazawa H, Ozono S, Horie S, et al. Prevalence of renal cell carcinoma: a nation-wide survey in Japan, 2002. Int J Urol. 2007 Jun;14(6):479-82.

25. Zheng R, Zeng H, Zhang S, Chen T, Chen W. National estimates of cancer prevalence in China, 2011. Cancer Lett. 2016 Jan 1;370(1):33-8.

26. Jung KH, Kim SM, Choi MG, Lee JH, Noh JH, Sohn TS, et al. Preoperative smoking cessation can reduce postoperative complications in gastric cancer surgery. Gastric Cancer. 2015 Oct;18(4):683-90.

27. Yi S-W. Cancer incidence in Korean Vietnam veterans during 1992-2003: the 
Korean veterans health study. J Prev Med public Heal = Yebang Ǔihakhoe chi. Korean Society for Preventive Medicine; 2013 Nov;46(6):309-18.

28. Luke C, Sargent N, Pittman K, Price T, Roder D. Epidemiology of cancers of the kidney in an Australian population. Asian Pac J Cancer Prev. 2011;12(11):2893-9.

29. Australian Institute of Health and Welfare. Cancer survival and prevalence in Australia: period estimates from 1982 to 2010. Asia Pac J Clin Oncol. 2013 Mar;9(1):29-39.

30. Badar F, Mahmood S, Yusuf MA, Sultan F. Epidemiology of cancers in Lahore, Pakistan, 2010-2012: a cross-sectional study. BMJ Open. 2016;6(6):e011828.

31. Abomelha MS. Trends of genitourinary cancer among Saudis. Arab J Urol. 2011 Sep;9(3):199-202.

32. Mirzaei M, Pournamdar Z, Salehiniya H. Epidemiology and Trends in Incidence of Kidney Cancer in Iran. Asian Pac J Cancer Prev. 2015;16(14):5859-61.

33. Tazi MA, Er-Raki A, Benjaafar N. Cancer incidence in Rabat, Morocco: 2006-2008. Ecancermedicalscience. Cancer Intelligence; 2013;7:338.

34. Pinheiro PS, Sherman RL, Trapido EJ, Fleming LE, Huang Y, Gomez-Marin O, et al. Cancer incidence in first generation U.S. Hispanics: Cubans, Mexicans, Puerto Ricans, and new Latinos. Cancer Epidemiol Biomarkers Prev. 2009 Aug;18(8):2162-9.

35. Gandaglia G, Ravi P, Abdollah F, Abd-El-Barr A-E-RM, Becker A, Popa I, et al. Contemporary incidence and mortality rates of kidney cancer in the United States. Can Urol Assoc J. 2014 Jul;8(7-8):247-52.

36. De P, Otterstatter MC, Semenciw R, Ellison LF, Marrett LD, Dryer D. Trends in incidence, mortality, and survival for kidney cancer in Canada, 1986-2007. Cancer Causes Control. 2014 Oct;25(10):1271-81.

37. Lang K, Danchenko N, Gondek K, Schwartz B, Thompson D. The burden of illness associated with renal cell carcinoma in the United States. Urol Oncol. 25(5):368-75.

38. Li C, Ekwueme DU, Rim SH, Tangka FK. Years of potential life lost and productivity losses from male urogenital cancer deaths-United States, 2004. Urology. Elsevier Inc.; 2010;76(3):528-35.

39. Kamel MH, Moore PC, Bissada NK, Heshmat SM. Potential years of life lost due to urogenital cancer in the United States: trends from 1972 to 2006 based on data from the SEER database. J Urol. 2012 Mar;187(3):868-71.

40. Chatenoud L, Bertuccio P, Bosetti C, Malvezzi M, Levi F, Negri E, et al. Trends in mortality from major cancers in the Americas: 1980-2010. Ann Oncol. 2014 Sep 1;25(9):1843-53.

41. Montes N, Tagle M. Epidemiología de los cánceres urológicos en la tercera región de Atacama. Rev Chil Urol. 2004;69(3):230-6.

42. Bosetti C, Rodríguez T, Chatenoud L, Bertuccio P, Levi F, Negri E, et al. Trends in 
cancer mortality in Mexico, 1981-2007. Eur J Cancer Prev. 2011 Sep;20(5):355-63.

43. Pardo, C. Cendales R. Incidencia, mortalidad y prevalencia de Cáncer en Colombia 2007-2011. Vol. 1, Instituto Nacional De Cancerologia. 2015. 148 p.

44. Guarnizo GL, Arias Ortiz N, Arboleda Ruiz W. Cancer incidence and mortality in Manizales 2003-2007. Colomb Med. 2012;43:281-9.

45. Uribe C, Osma S, Herrera V. Cancer incidence and mortality in the Bucaramanga metropolitan area, 2003-2007. Colomb Med. 2013;43:290-7.

46. Yepez MC, Bravo LE, Troya AH, Jurado DM, Bravo LM. Cancer incidence and mortality in the municipality of Pasto, 1998 - 2007. Colomb Med. 2012;43(Yépez MC):256-66.

47. Wojcieszak PZ, Poletajew S, Rutkowski D, Radziszewski P. The incidence of renal cancer in Polish National Cancer Registry: is there any epidemiological data we can rely on? Cent Eur J Urol. 2014;67(3):253-6.

48. Cancer Incidence in Five Continents Volume X - CI5X. Tables: indices of data quality [Internet]. World Health Organization. 2016 [cited 2017 Jul 24]. p. 1-5. Available from: http://ci5.iarc.fr/CI5-X/Pages/Indices_sel.aspx

49. Danzig MR, Weinberg AC, Ghandour RA, Kotamarti S, McKiernan JM, Badani KK. The association between socioeconomic status, renal cancer presentation, and survival in the United States: a survival, epidemiology, and end results analysis. Urology. 2014 Sep;84(3):583-9.

50. Armando Juliao Senior. Urología Colombiana, Ejercicio Profesional en Ciudades Intermedias. Urol Colomb. 9 No.3:212. 
Figures and Tables

Fig. 1. Flow chart of the search.

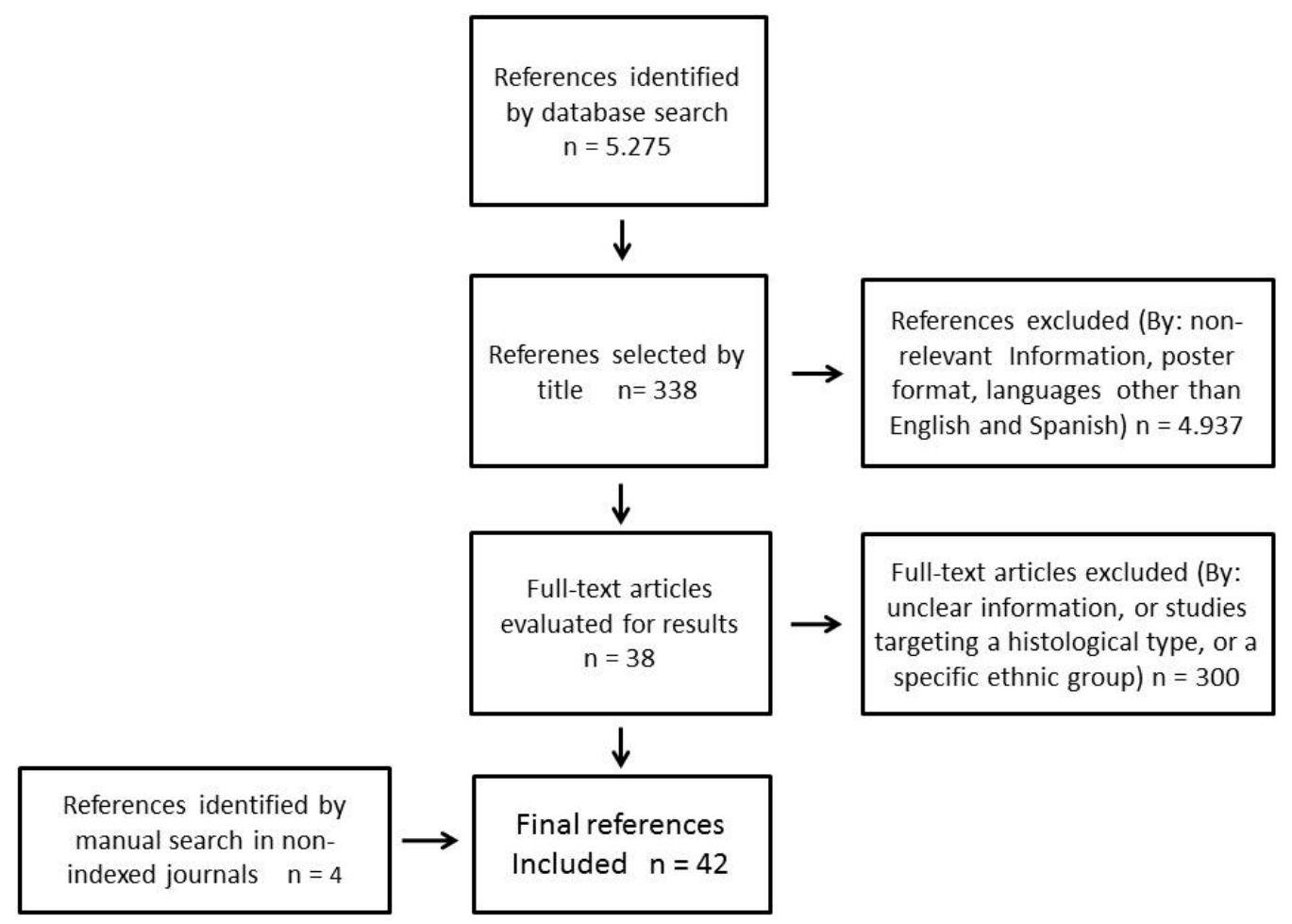


Table 1. Main outcomes of the search

\begin{tabular}{|c|c|c|c|c|c|}
\hline Author & Year & Journal & $\begin{array}{l}\text { Outcome } \\
\text { measure }\end{array}$ & Results & \begin{tabular}{|c|} 
Geographic \\
zone \\
\end{tabular} \\
\hline \multicolumn{6}{|l|}{ Global } \\
\hline Patel et $\mathrm{al}^{3}$ & 2012 & J Urol & Incidence & $\begin{array}{l}\text { North America } 11,8 / 100.000 \\
\text { Australia } 8,3 / 100.000 \text {; Europe } \\
8,1 / 100.000 \\
\text { Africa } 1,2 / 100.000 \text {; Asia } 1 / 100.000\end{array}$ & Global \\
\hline \multirow{2}{*}{ Znaor et al $^{1}$} & \multirow{2}{*}{2015} & \multirow{2}{*}{ Eur Urol } & Incidence & $\begin{array}{l}\text { Highest incidence was found in Czech } \\
\text { Republic of 9,9/100.000. Lowest in } \\
\text { Thailand of } 0,8 / 100.000\end{array}$ & \multirow{2}{*}{ Global } \\
\hline & & & Mortality & $\begin{array}{l}\text { Highest mortality was found in Czech } \\
\text { Republic of 3,6/100.000. Lowest in } \\
\text { Korea of } 0,6 / 100.000\end{array}$ & \\
\hline \multicolumn{6}{|l|}{ Europe } \\
\hline $\begin{array}{l}\text { Marcos- } \\
\text { Gragera et } \\
\mathrm{al}^{9}\end{array}$ & 2015 & $\begin{array}{l}\text { Eur J } \\
\text { Cancer }\end{array}$ & Survival & $\begin{array}{l}\text { North Europe } 55,8 \% \text { to } 5 \text { years } \\
\text { Central Europe } 64,6 \% \text { to } 5 \text { years } \\
\text { South Europe } 64,4 \% \text { to } 5 \text { years } \\
\text { East Europe } 57,5 \% \text { to } 5 \text { years }\end{array}$ & Europe \\
\hline Levi et $\mathrm{al}^{2}$ & 2008 & BJU Int & Mortality & $\begin{array}{l}\text { 1990-1994 Males of } 4,75 / 100.000 \\
\text { 1990-1994 Females of } 2,12 / 100.000 \\
\text { 2000-2004 Males of } 4,13 / 100.000 \\
\text { 2000-2004 Females of } 1,76 / 100.000\end{array}$ & Europe \\
\hline $\begin{array}{l}\text { Bosetti et } \\
\mathrm{al}^{19}\end{array}$ & 2011 & $\begin{array}{l}\text { Eur Assoc } \\
\text { Urol }\end{array}$ & Mortality & $\begin{array}{l}1994 \text { - 4,9/100.000 ; } 2006 \text { - 4,3/100.000 } \\
\text { Highest incidence in Czech Republic } \\
\text { males 9/100.000; females 3,7/100.000 } \\
\text { Lowest were found in Greece and } \\
\text { Portugal }\end{array}$ & Europe \\
\hline \multirow{2}{*}{$\begin{array}{l}\text { Ljungberg } \\
\text { et } \mathrm{al}^{4}\end{array}$} & \multirow{2}{*}{2011} & \multirow{2}{*}{ Eur Urol } & Incidence & $\begin{array}{l}\text { Males of } 15,8 / 100.000 \\
\text { Females of } 7,1 / 100.000\end{array}$ & \multirow{2}{*}{ Europe } \\
\hline & & & Mortality & $\begin{array}{l}\text { Males of } 6,5 / 100.000 \\
\text { Females of 2,7/100.000 }\end{array}$ & \\
\hline Stang et al ${ }^{12}$ & 2014 & \begin{tabular}{|l} 
Emerg \\
Themes \\
Epidemiol
\end{tabular} & Incidence & $\begin{array}{l}\text { Males of } 15,7 / 100.000 \\
\text { Females of 7,6/100.000 }\end{array}$ & Germany \\
\hline \begin{tabular}{|l} 
Van de \\
Schans et
\end{tabular} & 2012 & $\begin{array}{l}\text { Eur J } \\
\text { Cancer }\end{array}$ & Incidence & $\begin{array}{l}\text { Males of } 16,9 / 100.000 \\
\text { Females of } 9,2 / 100.000\end{array}$ & Holland \\
\hline
\end{tabular}




\begin{tabular}{|c|c|c|c|c|c|}
\hline $\mathrm{al}^{13}$ & & & Mortality & \begin{tabular}{|l} 
Males of $7,3 / 100.000$ \\
Females of $3,8 / 100.000$
\end{tabular} & \\
\hline \multirow{2}{*}{$\begin{array}{l}\text { Eriksen et } \\
\mathrm{al}^{22}\end{array}$} & \multirow{2}{*}{2008} & \multirow{2}{*}{$\begin{array}{l}\text { Eur J } \\
\text { Cancer }\end{array}$} & Incidence & \begin{tabular}{|c|} 
Males of $15 / 100.000$ \\
Females of $8 / 100.000$
\end{tabular} & \multirow{2}{*}{ Denmark } \\
\hline & & & Survival & $\begin{array}{l}\text { Males of } 39 \% \text { to } 5 \text { years } \\
\text { Females of } 44 \% \text { to } 5 \text { years }\end{array}$ & \\
\hline $\begin{array}{l}\text { Wihlborg et } \\
\text { al }^{17}\end{array}$ & 2009 & Urology & Incidence & \begin{tabular}{|l}
$1944-1948$ - Males 3,95/100.000 \\
1944-1948 - Females 2,72/100.000 \\
1969-1973 - Males 7,30/100.000 \\
1969-1973 - Females 4,77/100.000 \\
1999-2003 - Males 7,01/100.000 \\
1999-2003 - Females 3,6/100.000
\end{tabular} & Denmark \\
\hline $\begin{array}{l}\text { Maruthappu } \\
\text { et al }{ }^{18}\end{array}$ & 2015 & $\begin{array}{l}\text { BMC } \\
\text { Cancer }\end{array}$ & Incidence & $\begin{array}{l}\text { White people } 5.9 / 100.000 \text {; Black people } \\
5.5 / 100.000\end{array}$ & England \\
\hline \multirow{3}{*}{$\begin{array}{l}\text { Falebita et } \\
\mathrm{al}^{16}\end{array}$} & \multirow{3}{*}{2009} & \multirow{3}{*}{$\begin{array}{l}\text { Int Urol } \\
\text { Nephrol }\end{array}$} & Incidence & \begin{tabular}{|l|}
1994 - Males 7,1/100.000 \\
1994 - Females 3,3/100.000 \\
2005 - Males 8,0/100.000 \\
2005 - Females 5,7/100.000
\end{tabular} & \multirow{3}{*}{ Ireland } \\
\hline & & & Mortality & \begin{tabular}{|l|}
$1994-3,6 / 100.000$ \\
$2004-4,7 / 100.000$
\end{tabular} & \\
\hline & & & Survival & $\begin{array}{l}1994-1996-69,4 \% \text { to } 5 \text { years } \\
2000-2002-69,5 \% \text { to } 5 \text { years }\end{array}$ & \\
\hline \begin{tabular}{|l} 
Westlake et \\
$\mathrm{al}^{21}$
\end{tabular} & 2008 & Br J Cancer & Survival & Between $39 \%$ and $42 \%$ to 5 years & Scotland \\
\hline \multirow{2}{*}{$\begin{array}{l}\text { Souza et } \\
\mathrm{al}^{15}\end{array}$} & \multirow{2}{*}{2011} & \multirow{2}{*}{$\begin{array}{l}\text { Actas } \\
\text { Urológicas } \\
\text { Españolas }\end{array}$} & Prevalence & \begin{tabular}{|l|}
2002 - Males 53,65/100.000 \\
2002 - Females 23,04/100.000 \\
2012 - Males 57,1/100.000 \\
2012 - Females 44,08/100.000 \\
2022 - Males 59,57/100.000 \\
2022 - Females 81,37/100.000 \\
\end{tabular} & \multirow{2}{*}{ Spain } \\
\hline & & & Incidence & \begin{tabular}{|l|}
2002 - Males 8,79/100.000 \\
2002 - Females 4,92/100.000 \\
2012 - Males 9,17/100.000 \\
2012 - Females $8,97 / 100.000$ \\
2022 - Males 9,55/100.000 \\
2022 - Females 16,4/100.000
\end{tabular} & \\
\hline
\end{tabular}




\begin{tabular}{|c|c|c|c|c|c|}
\hline & & & Mortality & \begin{tabular}{|l}
2002 - Males 4,19/100.000 \\
2002 - Females 1,97/100.000 \\
2012 - Males 4,38/100.000 \\
2012 - Females 3,59/100.000 \\
2022 - Males 4,56/100.000 \\
2022 - Females 6,56/100.000
\end{tabular} & \\
\hline \multirow{2}{*}{$\begin{array}{l}\text { Clèries et } \\
\mathrm{al}^{14}\end{array}$} & \multirow{2}{*}{2013} & \multirow{2}{*}{$\begin{array}{l}\text { Clin Transl } \\
\text { Oncol }\end{array}$} & Mortality & $\begin{array}{l}\text { Males of } 2,3 / 100.000 \\
\text { Females of } 0,8 / 100.000\end{array}$ & \multirow{2}{*}{ Spain } \\
\hline & & & Incidence & $\begin{array}{l}\text { Males of } 8,2 / 100,000 \\
\text { Females of } 3,7 / 100,000\end{array}$ & \\
\hline Arfè et $\mathrm{al}^{20}$ & 2011 & $\begin{array}{l}\text { Eur J } \\
\text { Cancer } \\
\text { Prevent }\end{array}$ & Mortality & $\begin{array}{l}\text { Males of } 2,39 / 100.000 \\
\text { Females of } 1,61 / 100.000\end{array}$ & Italy \\
\hline \multicolumn{6}{|c|}{ Asia \& Oceania } \\
\hline $\begin{array}{l}\text { Marumo et } \\
\mathrm{al}^{24}\end{array}$ & 2007 & Int J Urol & Incidence & \begin{tabular}{|l|} 
Males of $8,2 / 100.000$ \\
Females of $3,6 / 100.000$
\end{tabular} & Japan \\
\hline $\begin{array}{l}\text { Marugame } \\
\text { et al }{ }^{23}\end{array}$ & 2006 & $\begin{array}{l}\text { Jap J Clin } \\
\text { Oncol }\end{array}$ & Incidence & $\begin{array}{l}\text { Males of } 11,6 / 100.000 \\
\text { Females of } 5,6 / 100.000\end{array}$ & Japan \\
\hline Yang et $\mathrm{al}^{10}$ & 2013 & PLOS ONE & Incidence & \begin{tabular}{|l|} 
Males of $5,64 / 100.000$ \\
Females of $3,33 / 100.000$
\end{tabular} & China \\
\hline $\begin{array}{l}\text { Zheng et } \\
\mathrm{al}^{25}\end{array}$ & 2015 & $\begin{array}{l}\text { Cancer } \\
\text { Letters }\end{array}$ & Prevalence & $\begin{array}{l}\text { Prevalence to } 5 \text { years for } 2011 \text { : } \\
\text { Males of } 17,9 / 100,000 \\
\text { Females of } 10,4 / 100,000\end{array}$ & China \\
\hline \multirow{3}{*}{ Jung et $\mathrm{al}^{26}$} & \multirow{3}{*}{2013} & \multirow{3}{*}{$\begin{array}{l}\text { Kor Cancer } \\
\text { Assoc }\end{array}$} & Incidence & $\begin{array}{l}\text { Males of } 10,1 / 100.000 \\
\text { Females of } 4,3 / 100.000\end{array}$ & \multirow{3}{*}{ Korea } \\
\hline & & & Mortality & $\begin{array}{l}\text { Males of } 2,3 / 100.000 \\
\text { Females of } 0,9 / 100.000\end{array}$ & \\
\hline & & & Survival & $77,7 \%$ to 5 years & \\
\hline Yi et $\mathrm{al}^{27}$ & 2013 & $\begin{array}{l}\text { J Prevent } \\
\text { Medicine } \\
\text { Public } \\
\text { Health }\end{array}$ & Incidence & $9,7 / 100.000$ & Korea \\
\hline \multirow{2}{*}{ Luke et $\mathrm{al}^{28}$} & \multirow{2}{*}{2011} & \multirow{2}{*}{$\begin{array}{l}\text { Asian } \\
\text { Pacific J } \\
\text { Cancer }\end{array}$} & Incidence & \begin{tabular}{|c|}
$1980-1984$ of $6,29 / 100.000$ \\
$2005-2008$ of $12,46 / 100.000$
\end{tabular} & \multirow{2}{*}{ Australia } \\
\hline & & & Mortality & $\begin{array}{c}1980-1984 \text { of } 3,39 / 100.000 \\
2005-2008 \text { of } 4,24 / 100.000\end{array}$ & \\
\hline
\end{tabular}




\begin{tabular}{|c|c|c|c|c|c|}
\hline & & & Survival & $61,7 \%$ to 5 years & \\
\hline $\begin{array}{l}\text { Australian } \\
\text { Institute of } \\
\text { Health and } \\
\text { Welfare }^{29}\end{array}$ & 2013 & $\begin{array}{l}\text { Asia Pacific } \\
\text { J Clin } \\
\text { Oncol }\end{array}$ & Survival & $\begin{array}{l}1982 \text { - } 1987 \text { de } 47 \% \text { to } 5 \text { years } \\
2006 \text { - } 2010 \text { de } 72 \% \text { to } 5 \text { years }\end{array}$ & Australia \\
\hline \multicolumn{6}{|c|}{ Africa \& Middle East } \\
\hline $\begin{array}{l}\text { Abomelha } \\
\text { et al }{ }^{31}\end{array}$ & 2011 & Arab J Urol & Incidence & $2,4 / 100.000$ & Arabia Saud \\
\hline $\begin{array}{l}\text { Mirzaei et } \\
\mathrm{al}^{32}\end{array}$ & 2015 & $\begin{array}{l}\text { Asian } \\
\text { Pacific J } \\
\text { Cancer } \\
\text { Prevent }\end{array}$ & Incidence & $\begin{array}{l}2003 \text { - Males of } 1,39 / 100.000 \\
2003 \text { - Females of } 0,96 / 100.000 \\
2009 \text { - Males of } 2,99 / 100.000 \\
2009 \text { - Females of } 2,05 / 100.000\end{array}$ & Iran \\
\hline $\begin{array}{l}\text { Badar et } \\
\mathrm{al}^{30}\end{array}$ & 2016 & BMJ Open & Incidence & $\begin{array}{l}2010-1,5 / 100.000 \\
2012-1,4 / 100.000\end{array}$ & Pakistan \\
\hline Tazi et al $^{33}$ & 2013 & E Cancer & Incidence & \begin{tabular}{|l|} 
Males of $2,3 / 100.000$ \\
Females of $1,7 / 100.000$
\end{tabular} & Morroco \\
\hline \multicolumn{6}{|l|}{ America } \\
\hline $\begin{array}{l}\text { Chatenoudet } \\
\mathrm{al}^{40}\end{array}$ & 2014 & $\begin{array}{l}\text { Annals } \\
\text { Oncol }\end{array}$ & $\begin{array}{l}\text { Mortality } \\
\text { in Males }\end{array}$ & \begin{tabular}{|l|} 
Uruguay $5,97 / 100.000$ \\
Argentina $4,85 / 100.000$ \\
Chile 4,2/100.000 \\
Brazil 1,71/100.000 \\
Colombia $1,25 / 100.000$ \\
Ecuador 1,17/100.000 \\
Uruguay $2,32 / 100.000$ \\
Chile 1,88/100.000 \\
Argentina $1,68 / 100.000$ \\
Colombia $0,79 / 100.000$ \\
Ecuador $0,76 / 100.000$
\end{tabular} & $\begin{array}{l}\text { Latin } \\
\text { America }\end{array}$ \\
\hline $\begin{array}{l}\text { Pinherio et } \\
\mathrm{al}^{34}\end{array}$ & 2009 & $\begin{array}{l}\text { Cancer } \\
\text { Epidemiol } \\
\text { Biomarkers } \\
\text { Prev }\end{array}$ & Incidence & \begin{tabular}{|l|} 
Males - Hispanic people17,3/100.000 \\
Males - White people 18/100.000 \\
Males - Black people 14,7/100.000. \\
Females - Hispanic people 7,7/100.000 \\
Females - White people 8,7/100.000 \\
Females - Black people 7,2/100.000.
\end{tabular} & USA \\
\hline Lang et $\mathrm{al}^{37}$ & 2007 & Urol Oncol & $\begin{array}{l}\text { Burden of } \\
\text { disease }\end{array}$ & $\begin{array}{l}\text { Anual cost for RCC up to } 2005 \text { was } \$ 4,4 \\
\text { billones [US], with a cost per patient of } \\
\$ 40.176 .92,4 \% \text { costs for medicines and }\end{array}$ & USA \\
\hline
\end{tabular}




\begin{tabular}{|c|c|c|c|c|c|}
\hline & & & & procedures ; 7,6 \% for disability & \\
\hline $\begin{array}{l}\text { Kamel et } \\
\mathrm{al}^{39}\end{array}$ & 2012 & J Urol & $\begin{array}{l}\text { Burden of } \\
\text { disease }\end{array}$ & $\begin{array}{l}\text { 1972-1976 of 343.912 PYLL. } \\
\text { 2002-2006 of 479.355 PYLL }\end{array}$ & USA \\
\hline Li et $\mathrm{al}^{38}$ & 2010 & Urology & $\begin{array}{l}\text { Burden of } \\
\text { disease }\end{array}$ & $\begin{array}{l}\text { YPLL White people } 104.126 \text { [50,59 \%] } \\
\text { YPLL Black people } 112.438 \text { [62,10 \%] } \\
\text { YPLL Hispanic people } 10.010[72,81 \%] \\
\text { YPLL General 129.216 [52,94 \%] }\end{array}$ & USA \\
\hline \multirow{3}{*}{$\begin{array}{l}\text { Gandaglia et } \\
\mathrm{al}^{35}\end{array}$} & \multirow{3}{*}{2014} & \multirow{3}{*}{$\begin{array}{l}\text { Can Urol } \\
\text { Assoc J }\end{array}$} & Incidence & \begin{tabular}{|c|}
$1975-2,99 / 100.000$ \\
$2009-12,16 / 100.000$
\end{tabular} & \multirow{3}{*}{ USA } \\
\hline & & & Mortality & \begin{tabular}{|l|}
$1975-2,24 / 100.000$ \\
$2009-5 / 100.000$
\end{tabular} & \\
\hline & & & Survival & $\begin{array}{l}1975-47,5 \% \text { to } 5 \text { years } \\
2005-64,9 \% \text { to } 5 \text { years }\end{array}$ & \\
\hline \multirow{3}{*}{$\begin{array}{l}\text { Otterstatter } \\
\text { et } \mathrm{al}^{36}\end{array}$} & \multirow{3}{*}{2014} & \multirow{3}{*}{$\begin{array}{l}\text { Cancer } \\
\text { Causes } \\
\text { Control }\end{array}$} & Incidence & $\begin{array}{l}1986 \text { - Males of } 13,4 / 100.000 \\
1986 \text { - Females of } 7,7 / 100.000 \\
2007 \text { - Males of } 17,9 / 100.000 \\
2007 \text { - Females of } 10,3 / 100.000\end{array}$ & \multirow{3}{*}{ Canada } \\
\hline & & & Mortality & $\begin{array}{l}\text { To } 2025 \text { males mortality will be } \\
17,9 / 100.000 \text {. To } 2025 \text { females mortality } \\
\text { will be } 8,7 / 100.000\end{array}$ & \\
\hline & & & Survival & $68 \%$ to 5 years & \\
\hline $\begin{array}{l}\text { Montes et } \\
\mathrm{al}^{41}\end{array}$ & 2004 & $\begin{array}{l}\text { Revista } \\
\text { Chilena de } \\
\text { Urología }\end{array}$ & Incidence & $\begin{array}{l}\text { General of } 6,95 / 100.000 \\
\text { Males of } 9,67 / 100.000 \\
\text { Females of } 4,14 / 100.000\end{array}$ & Chile \\
\hline $\begin{array}{l}\text { Villanueva } \\
\text { et } \mathrm{al}^{11}\end{array}$ & 2014 & $\begin{array}{l}\text { Gaceta } \\
\text { Médica de } \\
\text { México }\end{array}$ & Incidence & $2,5 / 100.000$ & Mexico \\
\hline \multirow{2}{*}{$\begin{array}{l}\text { Bosetti et } \\
\mathrm{al}^{42}\end{array}$} & \multirow{2}{*}{2011} & \multirow{2}{*}{$\begin{array}{l}\text { Eur J Cancer } \\
\text { Prevent }\end{array}$} & \multirow{2}{*}{ Mortality } & $\begin{array}{l}1999 \text { - Males of 2,2/100.000 } \\
1999 \text { - Females of 2,35/100.000 }\end{array}$ & \multirow{2}{*}{ Mexico } \\
\hline & & & & \begin{tabular}{|l|}
2007 - Males of $2,35 / 100.000$ \\
2007 - Females of $1,34 / 100.000$
\end{tabular} & \\
\hline $\begin{array}{l}\text { Guarnizo et } \\
\mathrm{al}^{44}\end{array}$ & 2012 & $\begin{array}{l}\text { Colombia } \\
\text { Médica }\end{array}$ & Incidence & $\begin{array}{l}\text { Males of } 3,4 / 100.000 \\
\text { Females of } 2,4 / 100.000\end{array}$ & Colombia \\
\hline $\begin{array}{l}\text { Uribe et } \\
\mathrm{al}^{45}\end{array}$ & 2012 & $\begin{array}{l}\text { Colombia } \\
\text { Médica }\end{array}$ & Incidence & $\begin{array}{l}\text { Males of } 2,4 / 100.00 \\
\text { Females of } 1,3 / 100.000\end{array}$ & Colombia \\
\hline
\end{tabular}




\begin{tabular}{|c|c|c|c|c|c|}
\hline $\begin{array}{l}\text { Yépez et } \\
\mathrm{al}^{46}\end{array}$ & 2012 & $\begin{array}{l}\text { Colombia } \\
\text { Médica }\end{array}$ & Incidence & \begin{tabular}{|l} 
1998-2002 Males of $2,1 / 100.000$ \\
1998-2002 Females of $1,1 / 100.000$ \\
2003-2007 Males of $1,7 / 100.000$ \\
2003-2007 Females of $1,4 / 100.000$
\end{tabular} & Colombia \\
\hline \multirow{3}{*}{ Pardo et al ${ }^{43}$} & \multirow{3}{*}{2015} & \multirow{3}{*}{$\begin{array}{l}\text { Instituto } \\
\text { Nacional de } \\
\text { Cancerologí } \\
a\end{array}$} & Incidence & $\begin{array}{l}\text { Males of } 2,7 / 100.000 \\
\text { Females of } 1,9 / 100.000\end{array}$ & \multirow{3}{*}{ Colombia } \\
\hline & & & Mortality & $\begin{array}{l}\text { Males of } 1,1 / 100.000 \\
\text { Females of } 0,7 / 100.000\end{array}$ & \\
\hline & & & Survival & Absolute survival of 51,9 \% to 5 years & \\
\hline
\end{tabular}

